\title{
Assessment of labor room communication skills among postgraduate students of obstetrics and gynecology
}

\author{
Amit Gupta ${ }^{1 *}$, Bharti Gupta ${ }^{2}$, Ashok Verma1 ${ }^{1}$, Chanderdeep Sharma ${ }^{1}$, Sita Thakur ${ }^{1}$, \\ Anjali Soni ${ }^{1}$
}

\begin{abstract}
${ }^{1}$ Department of Obstetrics and Gynecology, DRPGMC, Kangra (Tanda), Himachal Pradesh, India
${ }^{2}$ Department of Anesthesia, DRPGMC, Kangra (Tanda), Himachal Pradesh, India
\end{abstract}

Received: 03 April 2020

Accepted: 29 April 2020

\section{*Correspondence:}

Dr. Amit Gupta,

E-mail: dramit203@gmail.com

Copyright: (C) the author(s), publisher and licensee Medip Academy. This is an open-access article distributed under the terms of the Creative Commons Attribution Non-Commercial License, which permits unrestricted non-commercial use, distribution, and reproduction in any medium, provided the original work is properly cited.

\begin{abstract}
Background: "Communication with patients" is an important skill needed for every physician in their clinical practice. These soft skills are required in dealing with patients at every step which include history taking from the patients, explaining them the diagnosis, the prognosis of the disease with associated complications. Dealing with empathy, taking informed consent, explaining the operative procedure and the complications associated with surgery, the art of breaking bad news are the mandatory skills for a good clinician. Labouring women like other patients also require special attention and empathy. So, the residents working in labor room need commitment to develop these soft skills in order to improve the labor room experience of expectant mothers. Objective of this study was to analyse role of a formal training in labor room communication skills among post graduate students of the department of obstetrics and gynecology.

Methods: Faculty and students' sensitization was done after approval from institutional 'ethics committee' for conducting this study. Pre-workshop assessment of residents for communication skills attitude and effective communication was done through 'communication skill attitude scale' (CSAS) and 'GAP-KALAMAZOO scale'. Workshop for communication skills on the framework of Calgary Cambridge patient interview model and online teaching of students through what's app videos, role-play demonstrations was followed by reassessment of the residents through above used scales.

Results: Results depicted both improvements in attitude and effective communication skills among residents. $100 \%$ of the students were convinced and opined that good communication skills necessary for perfect clinical practice.

Conclusions: The skill to communicate with patients is a fine art and needs to be mastered to be a good clinician. A formal training in effective communication skills is absolutely necessary to bring professionalism in medical practice.
\end{abstract}

Keywords: Communication skills, Labor room, Parturient, Post graduate students

\section{INTRODUCTION}

"Communication with patients" is one of the core clinical skills which every physician needs to possess. These skills include the art of history taking from the patients, explaining the diagnosis, the prognosis and the risk of associated complications, taking informed consent, detailing preoperative orders to the patients undergoing diagnostic and therapeutic procedures, giving therapeutic instructions, the art of breaking bad news and counselling the patients for compliance in treatment and needed lifestyle modifications. ${ }^{1-3}$ Traditional medical teaching imparts students with theoretical and practical knowledge that addresses their cognitive and psychomotor domains only and does not teach them the communication skills which are most essential in dealing 
with patients, specially laboring women. ${ }^{4,5}$ Establishment of good doctor-patient relationship is proportional to god communication skills. Good communications and counselling techniques can be taught and practiced in labor room to improve patient cooperation during labor, decrease maternal and fetal complications and increase maternal satisfaction thus improving doctor patient relationship.

As per WHO guidelines published in February, 2018, it recommends effective communication, using simple and culturally acceptable methods, between maternity care providers and women in labor. ${ }^{6}$ Communicating softly with the patients, listening them carefully with supportive and empathetic attitude is key to establish good rapport with them. Patients appreciate those doctors who listen them actively, encourage them clear their doubts, value their privacy and comfort. Non-verbal communications such as body language, facial expression, touch, gestures eye contact, are important parameters for effective doctor patient relationship.

Arrogance, talking to patients using medical terminology and not in the language that patient can understand, giving inadequate time for doctor patient encounter are some of the factors detrimental to effective communication which creates misconduct and may lead to medico legal complications. ${ }^{8}$ Usually, in the absence of formal teaching, students learn communications skills from their seniors or teachers by observing them so may learn good as well as bad soft skills that their seniors or teacher possess. Several professional bodies and also The Vision 2015 document of the MCI advocate the need to incorporate communication skills training within the formal curriculum of medical students. ${ }^{9}$

\section{Aims and objectives}

- To assess and improve labor room communication skills among post graduate students of the department of obstetrics and gynecology.

- To improve confidence of the students in communicating with patients.

- To improve labor room experience of the parturing mother.

\section{METHODS}

After taking approval from institutional ethics and research committees, this study was conducted in department of obstetrics and gynecology of Dr Rajendra Prasad Govt. Medical College, Kangra (Tanda) on communication skills between post graduate students and laboring patients in the month of August 2019. $1^{\text {st }}$ year post graduate students were excluded from the study as their labor room experience was less and they had very little knowledge about the working of department.

A sensitization programme for participating faculty and students regarding the study was conducted and the purpose and nature of the study will be explained.

Table 1: Gap-Kalamazoo communication skill assessment form (GKCSAF).

Competency and sub-competency

A. Builds a relationship

a. Greets and shows interest in the patient and patient's family

b. Uses words that show care and concern throughout the interview

c. Uses tone, pace, eye contact, and posture that show care and concern

d. Responds explicitly to patient and family statements about ideas and feelings

B. Opens the discussion

a. Allows patient and family to complete opening statements without interruption

b. Asks "Is there anything else?" to elicit full set of concerns

c. Explains and/or negotiates an agenda for the visit

C. Gathers information

a. Addresses patient and family statements using open-ended questions.

b. Clarifies details as necessary with more specific or "yes/no" questions

c. Summarizes and gives family opportunity to correct or add information

d. Transitions effectively to additional questions

D. Understands the patient's and family's perspective

a. Asks about life events, circumstances, other people that might affect health

b. Elicits patient's and family's beliefs, concerns, and expectations about illness and treatment

E. Shares information

a. Assesses patient's and family's understanding of problems and desire for more
Score (Likert scale)

\begin{tabular}{|ll|}
\hline Poor & 1 \\
\hline Fair & 2 \\
\hline Good & 3 \\
\hline Very good & 4 \\
\hline Excellent & 5 \\
\hline Poor & 1 \\
\hline Fair & 2 \\
\hline Good & 3 \\
\hline Very good & 4 \\
\hline Excellent & 5 \\
\hline Poor & 1 \\
\hline Fair & 2 \\
\hline Good & 3 \\
\hline Very good & 4 \\
\hline Excellent & 5 \\
\hline Poor & 1 \\
\hline Fair & 2 \\
\hline Good & 3 \\
\hline Very good & 4 \\
\hline Excellent & 5 \\
\hline Poor & 1 \\
\hline Fair & 2 \\
\hline
\end{tabular}

Volume 9 - Issue 6 Page 2282 
b. Explains using words that family can understand

c. Asks if family has any questions

F. Reaches agreement (If new/changed plan)

a. Includes family in choices and decisions to the extent they desire.

b. Checks for mutual understanding of diagnostic and/or treatment plans

c. Asks about acceptability of diagnostic and/or treatment plans

d. Identifies additional resources as appropriate

\begin{tabular}{|ll|}
\hline Good & 3 \\
\hline Very good & 4 \\
\hline Excellent & 5 \\
\hline Poor & 1 \\
\hline Fair & 2 \\
\hline Good & 3 \\
\hline Very good & 4 \\
\hline Excellent & 5 \\
\hline Poor & 1 \\
\hline Fair & 2 \\
\hline Good & 3 \\
\hline Very good & 4 \\
\hline Excellent & 5 \\
\hline Poor & 1 \\
\hline Fair & 2 \\
\hline Good & 3 \\
\hline Very good & 4 \\
\hline Excellent & 5 \\
\hline Poor & 1 \\
\hline Fair & 2 \\
\hline Good & 3 \\
\hline Very good & 4 \\
\hline Excellent & 5 \\
\hline
\end{tabular}

G. Provides closure

a. Asks if patient and family have questions, concerns or other issues

b. Summarizes

c. Clarifies future time when progress will again be discussed

d. Provides appropriate contact information if interim questions arise

e. Acknowledges patient and family, and closes interview

H. Demonstrates empathy

a. Clinician's demeanour is appropriate to the nature of the conversation

b. Shows compassion and concern

c. Identifies/labels/validates patient's and family's emotional responses

d. Responds appropriately to patient and family's emotional cues

I. Communicates accurate information

a. Accurately conveys the relative seriousness of patient's condition.

b. Took other participating clinician's input into account.

c. Clearly conveys expected disease course.

d. Clearly presents and explains options for future care.

e. Gives enough clear information to empower decision making

Students' pre-workshop attitude towards importance and learning of communication skills was assessed using Communication Skills Attitude Scale (CSAS). ${ }^{10}$ CSAS consists of 26 items, 13 of which are written in the form of positive statements and 13 negative statements about communication skills learning. Each item is accompanied by a 5-point Likert scale.

Also, their pre-workshop knowledge about effective communication skills was assessed by observing their encounter with the patients by faculty of obstetrics and gynecology, self-assessment done by students themselves and 100 patients/attendants recruited for study after due consent for their labor room experience using gapkalamazoo communication skill assessment form (GKCSAF). ${ }^{11-13}$ Both patient satisfaction questionnaire (PSQ) communication competence using self-rating communication competence questionnaire (SRCCQ) were based on KALAMAZOO scale.

GKCSAF (Table 1) includes 9 evidence-based core communication competencies and 34 sub competencies to assess effective physician-patient relation (build a relationship; open the discussion; gather information; understand patient's prospective; share information; reach agreement; provide closure; demonstrates empathy; and communicates accurate information).

Workshop for communication skills (both verbal and nonverbal) was conducted for participating students using a framework of Calgary Cambridge patient interview model through interactive lectures, small group discussions, sharing videos through Whatsapp, and role play demonstrations by the students themselves about doctor-patient encounters. ${ }^{14}$ WHO recommendations on effective communications, published in February 2018 were discussed. ${ }^{6}$ Further students were advised to do selfdirected learning using internet. Again, after workshop students were reassessed by post training CSAS questionnaire and GKCSAF by faculty. The students again did self-assessment of communication competence using self-rating communication competence questionnaire (SRCCQ based on KALAMAZOO scale). Another set of 100 patients were assessed by patient satisfaction questionnaire (PSQ based on KALAMAZOO scale) about their labor room experience. Data collected was compiled and analyzed by Epi-info software version 3. Descriptive statistics, means and standard deviations were calculated for socio-demographic profile, CSAS score. Results for effective communication skills, observed through KALAMAZOO scale, were analyzed by "two sample independent ' $t$ '-test".

\section{RESULTS}

\section{Socio-demographic profile}

Mean age of the participants was 28.86 years. $4(13.8 \%)$ were males and $25(86.3 \%)$ were females. $15(51.8 \%)$ 
students were in $2^{\text {nd }}$ year while $14(48.2 \%)$ students were in $3^{\text {rd }}$ year of their residency programme (Table 2 ).

Table 2: Students' profile.

\begin{tabular}{|lll|}
\hline & Male & Female \\
\hline $2^{\text {nd }}$ year & 0 & 15 \\
\hline $3^{\text {rd }}$ year & 4 & 10 \\
\hline Total & 4 & 25 \\
\hline
\end{tabular}

Chi-square test $\left(\mathrm{x}^{2}=4.9, \mathrm{Df}=1\right.$ and $\left.\mathrm{p}=0.02577\right)$.

A total $27(93.1 \%)$ students were of the opinion that role plays and videos were the most effective method of learning and improving communication skills while 2 $(6.9 \%)$ stated that they learnt better through demonstrations.

\section{CSAS (communication skills attitude scale) observations}

Pre workshop attitude of the students for learning communication skills was assessed using communication skill assessment scale. $21(72.4 \%)$ students were of the view that doctor patient communication is very important while post workshop all the students $(n=29,100 \%)$ changed their opinion and opined that the communications skills are the integral part of clinical skills and are absolutely necessary for good doctor patient relationship. $28(96.5 \%)$ students felt more confident in treating patients after learning communication skills. 27 $(93.1 \%)$ of the students were of the view that learning these soft skills will be helpful in their future practice also while these pre-workshop figures were $24(82.7 \%)$ and $23(79.3 \%)$ respectively (Table 3 ).

Positive attitude for learning communication skills increased from $25(86.3 \%)$ to $100 \%$ after the workshop.

All the students $(n=29,100 \%)$ were convinced with the utility of communication skills in medical practice and were of the view that a formal training on these soft skills should be introduced in their teaching schedule in the $1^{\text {st }}$ year of their residency programme.

\section{Work place assessment}

Labor room communication skills of the students were assessed by faculty, self-assessment done by students themselves and patients/attendants using GAPKALAMAZOO scale both before and after the workshop.

It was observed that there was significant improvement in all the skill competencies assessed by faculty (Table 4) as the $p$ value was significant in all except competency ' $F$ '. Even the self-assessment done by students themselves (Table 5) depicted the improvement in all the examined parameters of communication skills except ' $\mathrm{C}$ '.

However, the results were different in the patients/attendants assessed communication skill competencies as the $\mathrm{p}$ value was only significant in 4 out of 9 parameters ' $B, F, G, H$ '. There was significant $p$ value in competency ' $G$ ' indicating significant improvement in empathy among residents after workshop (Table 6).

Table 3: Communication skills aptitude.

\begin{tabular}{|llllllll|} 
& Important & \multicolumn{3}{c}{ Doctor-patient relationship improved } & \multicolumn{3}{c|}{ Helpful in future practice } \\
& Yes & No & Yes & No & Yes & No \\
\hline Pre-workshop & 21 & 8 & 24 & 5 & 23 & 6 \\
\hline Post-workshop & 29 & - & 28 & 01 & 27 & 02 \\
\hline
\end{tabular}

Chi-square test $\left(\mathrm{x}^{2}=14.57, \mathrm{Df}=5\right.$ and $\left.\mathrm{p}=0.01234\right)$.

Table 4: Faculty assessment using KALAMAZOO assessment scale.

\begin{tabular}{|c|c|c|c|c|c|c|}
\hline & $\begin{array}{l}\text { Pre-workshop } \\
\mathrm{n}=29\end{array}$ & $\begin{array}{l}\text { Post- workshop } \\
n=29\end{array}$ & p value & CI & $\begin{array}{l}\text { Lower } \\
\text { limit }\end{array}$ & $\begin{array}{l}\text { Upper } \\
\text { limit }\end{array}$ \\
\hline Builds a relationship & $\begin{array}{l}\text { Mean }=2.72 \\
\mathrm{SD}=0.441\end{array}$ & $\begin{array}{l}\text { Mean }=3.52 \\
\mathrm{SD}=0.509\end{array}$ & $<0.0000001$ & $95 \%$ & -1.05396 & -0.546035 \\
\hline Opens the discussion & $\begin{array}{l}\text { Mean }=2.75 \\
S D=0.455\end{array}$ & $\begin{array}{l}\text { Mean }=3.56 \\
S D=0.506\end{array}$ & $<0.0000001$ & $95 \%$ & -1.06232 & -0.557682 \\
\hline Gathers information & $\begin{array}{l}\text { Mean }=3.31 \\
\mathrm{SD}=0.541\end{array}$ & $\begin{array}{l}\text { Mean }=3.59 \\
\mathrm{SD}=0.501\end{array}$ & $<0.04557$ & $95 \%$ & 0.554286 & -0.005714 \\
\hline $\begin{array}{l}\text { Understands the patient's } \\
\text { and family's perspective }\end{array}$ & $\begin{array}{l}\text { Mean }=2.48 \\
\mathrm{SD}=0.509\end{array}$ & $\begin{array}{l}\text { Mean }=3.07 \\
\mathrm{SD}=0.258\end{array}$ & 0.0000007 & $95 \%$ & -0.802277 & -0.377723 \\
\hline Shares information & $\begin{array}{l}\text { Mean }=2.34 \\
\mathrm{SD}=0.484\end{array}$ & $\begin{array}{l}\text { Mean }=3.21 \\
\mathrm{SD}=0.412\end{array}$ & $<0.0000001$ & $95 \%$ & -1.10644 & -0.63356 \\
\hline $\begin{array}{l}\text { Reaches agreement (if } \\
\text { new/changed plan) }\end{array}$ & $\begin{array}{l}\text { Mean }=2.69 \\
S D=0.471\end{array}$ & $\begin{array}{l}\text { Mean }=2.83 \\
\mathrm{SD}=0.384\end{array}$ & 0.2199 & $95 \%$ & -0.36605 & 0.086057 \\
\hline
\end{tabular}




\begin{tabular}{|c|c|c|c|c|c|c|}
\hline & $\begin{array}{l}\text { Pre-workshop } \\
\text { n=29 }\end{array}$ & $\begin{array}{l}\text { Post- workshop } \\
\mathrm{n}=29\end{array}$ & p value & $\mathbf{C I}$ & $\begin{array}{l}\text { Lower } \\
\text { limit }\end{array}$ & $\begin{array}{l}\text { Upper } \\
\text { limit }\end{array}$ \\
\hline Provides closure & $\begin{array}{l}\text { Mean }=3.03 \\
\mathrm{SD}=0.421\end{array}$ & $\begin{array}{l}\text { Mean }=3.52 \\
\mathrm{SD}=0.509\end{array}$ & 0.0001909 & $95 \%$ & -0.735716 & -0.244284 \\
\hline Demonstrates empathy & $\begin{array}{l}\text { Mean }=2.52 \\
\mathrm{SD}=0.574\end{array}$ & $\begin{array}{l}\text { Mean }=3.52 \\
\mathrm{SD}=0.509\end{array}$ & $<0.0000001$ & $95 \%$ & -1.28538 & -0.714619 \\
\hline $\begin{array}{l}\text { Communicates accurate } \\
\text { information }\end{array}$ & $\begin{array}{l}\text { Mean }=2.9 \\
\mathrm{SD}=0.31\end{array}$ & $\begin{array}{l}\text { Mean=3.59 } \\
\mathrm{SD}=0.501\end{array}$ & $<0.0000001$ & $95 \%$ & -0.910091 & -0.469909 \\
\hline
\end{tabular}

$\mathrm{CI}=$ Confidence limit .

Table 5: Self-assessment of communication skills by students using KALAMAZOO assessment scale (SRCCQ).

\begin{tabular}{|c|c|c|c|c|c|c|}
\hline & $\begin{array}{l}\text { Pre-workshop } \\
\text { n=29 }\end{array}$ & $\begin{array}{l}\text { Post- workshop } \\
n=29\end{array}$ & p value & CI & $\begin{array}{l}\text { Lower } \\
\text { limit }\end{array}$ & $\begin{array}{l}\text { Upper } \\
\text { limit }\end{array}$ \\
\hline Builds a relationship & $\begin{array}{l}\text { Mean }=3.31 \\
\mathrm{SD}=0.471\end{array}$ & $\begin{array}{l}\text { Mean }=4.0 \\
S D=0.267\end{array}$ & $<0.0000001$ & $95 \%$ & -0.89262 & -0.48738 \\
\hline Opens the discussion & $\begin{array}{l}\text { Mean=3.59 } \\
\mathrm{SD}=0.501\end{array}$ & $\begin{array}{l}\text { Mean=3.9 } \\
\mathrm{SD}=0.489\end{array}$ & 0.02051 & $95 \%$ & -0.570425 & -0.0495749 \\
\hline Gathers information & $\begin{array}{l}\text { Mean }=3.69 \\
\mathrm{SD}=0.471\end{array}$ & $\begin{array}{l}\text { Mean=3.9 } \\
\mathrm{SD}=0.31\end{array}$ & 0.05055 & $95 \%$ & -0.420527 & 0.00052743 \\
\hline $\begin{array}{l}\text { Understands the patient's } \\
\text { and family's perspective }\end{array}$ & $\begin{array}{l}\text { Mean }=3.86 \\
\mathrm{SD}=0.693\end{array}$ & $\begin{array}{l}\text { Mean }=4.0 \\
\mathrm{SD}=0.267\end{array}$ & 0.3168 & $95 \%$ & -0.419691 & 0.139691 \\
\hline Shares information & $\begin{array}{l}\text { Mean }=3.66 \\
\mathrm{SD}=0.484\end{array}$ & $\begin{array}{l}\text { Mean }=3.93 \\
\mathrm{SD}=0.258\end{array}$ & 0.01119 & $95 \%$ & -0.475398 & -0.0646019 \\
\hline $\begin{array}{l}\text { Reaches agreement (if } \\
\text { new/changed plan) }\end{array}$ & $\begin{array}{l}\text { Mean }=3.72 \\
\mathrm{SD}=0.455\end{array}$ & $\begin{array}{l}\text { Mean }=4.1 \\
\mathrm{SD}=0.409\end{array}$ & 0.01474 & $95 \%$ & -0.607585 & -0.152415 \\
\hline Provides closure & $\begin{array}{l}\text { Mean }=3.76 \\
\mathrm{SD}=0.511\end{array}$ & $\begin{array}{l}\text { Mean }=4.03 \\
\mathrm{SD}=0.186\end{array}$ & 0.01132 & $95 \%$ & -0.475001 & -0.0649994 \\
\hline Demonstrates empathy & $\begin{array}{l}\text { Mean=3.69 } \\
\mathrm{SD}=0.471\end{array}$ & $\begin{array}{l}\text { Mean }=4.0 \\
\mathrm{SD}=0\end{array}$ & 0.01404 & $95 \%$ & -0.48916 & -0.13084 \\
\hline $\begin{array}{l}\text { Communicates accurate } \\
\text { information }\end{array}$ & $\begin{array}{l}\text { Mean }=3.62 \\
\mathrm{SD}=0.494\end{array}$ & $\begin{array}{l}\text { Mean }=3.97 \\
\mathrm{SD}=0.186\end{array}$ & 0.001033 & $95 \%$ & -0.548795 & -0.151205 \\
\hline
\end{tabular}

SRCCQ: Self-rating communication competence questionnaire, CI: Confidence limit.

Table 6: Assessment of communication skills by patients using KALAMAZOO assessment scale (PSQ).

\begin{tabular}{|c|c|c|c|c|c|c|}
\hline & $\begin{array}{l}\text { Pre-workshop } \\
\text { n=100 }\end{array}$ & $\begin{array}{l}\text { Post- workshop } \\
n=100\end{array}$ & p value & CI & $\begin{array}{l}\text { Lower } \\
\text { limit }\end{array}$ & $\begin{array}{l}\text { Upper } \\
\text { limit }\end{array}$ \\
\hline Builds a relationship & $\begin{array}{l}\text { Mean }=2.77 \\
\mathrm{SD}=0.468\end{array}$ & $\begin{array}{l}\text { Mean }=2.87 \\
\mathrm{SD}=3.338\end{array}$ & 0.7673 & $95 \%$ & -0.768489 & 0.568489 \\
\hline Opens the discussion & $\begin{array}{l}\text { Mean }=2.32 \\
\mathrm{SD}=0.75\end{array}$ & $\begin{array}{l}\text { Mean }=2.57 \\
\mathrm{SD}=0.573\end{array}$ & 0.008777 & $95 \%$ & -0.436208 & -0.0637923 \\
\hline Gathers information & $\begin{array}{l}\text { Mean }=2.63 \\
S D=0.544\end{array}$ & $\begin{array}{l}\text { Mean }=2.55 \\
\mathrm{SD}=0.592\end{array}$ & 0.3209 & $95 \%$ & -0.078547 & 0.238547 \\
\hline $\begin{array}{l}\text { Understands the patient's } \\
\text { and family's perspective }\end{array}$ & $\begin{array}{l}\text { Mean }=2.43 \\
\mathrm{SD}=0.782\end{array}$ & $\begin{array}{l}\text { Mean }=2.38 \\
\mathrm{SD}=0.616\end{array}$ & 0.6161 & $95 \%$ & -0.146376 & 0.246376 \\
\hline Shares information & $\begin{array}{l}\text { Mean }=1.98 \\
\mathrm{SD}=0.586\end{array}$ & $\begin{array}{l}\text { Mean }=2.1 \\
\mathrm{SD}=0.611\end{array}$ & 0.1579 & $95 \%$ & -0.286948 & 0.046948 \\
\hline $\begin{array}{l}\text { Reaches agreement (if } \\
\text { new/changed plan) }\end{array}$ & $\begin{array}{l}\text { Mean }=2.09 \\
\mathrm{SD}=0.588\end{array}$ & $\begin{array}{l}\text { Mean }=2.46 \\
\mathrm{SD}=0.558\end{array}$ & 0.0000087 & $95 \%$ & -0.529855 & -0.210145 \\
\hline Provides closure & $\begin{array}{l}\text { Mean }=2.31 \\
\mathrm{SD}=0.486\end{array}$ & $\begin{array}{l}\text { Mean }=2.52 \\
\mathrm{SD}=0.502\end{array}$ & 0.002994 & $95 \%$ & -0.347786 & -0.0722136 \\
\hline Demonstrates empathy & $\begin{array}{l}\text { Mean }=2.05 \\
\mathrm{SD}=0.5\end{array}$ & $\begin{array}{l}\text { Mean=2.39 } \\
\mathrm{SD}=0.53\end{array}$ & 0.00000564 & $95 \%$ & -0.483686 & -0.196314 \\
\hline $\begin{array}{l}\text { Communicates accurate } \\
\text { information }\end{array}$ & $\begin{array}{l}\text { Mean }=2.48 \\
\mathrm{SD}=0.541\end{array}$ & $\begin{array}{l}\text { Mean }=2.67 \\
\mathrm{SD}=0.533\end{array}$ & 0.1317 & $95 \%$ & -0.339764 & -0.0402355 \\
\hline
\end{tabular}

PSQ: Patient satisfaction questionnaire, CI: Confidence limit. 


\section{DISCUSSION}

Good communication skills are an important art for good clinical practice. In tradition teaching there is no formal training and students learn these skills by observing their seniors, teachers and mentors.

Chaudhary et al. studied the attitude of the students towards learning the communication skills and found that only $78.1 \%$ of the student exhibited positive attitude towards learning these soft skills. ${ }^{3}$ In a similar study by Laiane and associates observed the improvement in communication skill attitude in $80 \%$ of their participants. $^{15} 80 \%$ of the students admitted that there was significant improvement in their communication skills after the workshop. In the present study, before workshop, $21(72.4 \%)$ students were of the view that doctor patient communication is very important while post workshop all the students $(n=29,100 \%)$ admitted that these are absolutely necessary for being good clinician. The improvement in the CSAS score was in agreement with the study done by Laiane and associates. ${ }^{15}$ Wright et al, also studied students' attitude toward learning these skills. ${ }^{16}$

They observed that the positive attitude increases by perceived relevance of the skills by the students. In the present study, high attitude of our residents for learning these communication skills was due to fact that they were aware of the importance of these skills. So the results of our study are concordant to the findings made Wright et al. in their studies. ${ }^{16}$ Isabel et al, stated that $100 \%$ of the students were of the view that communication skills are important, affects doctor's competence and professional satisfaction. ${ }^{17}$ These findings were in accordance to our study, post workshop all the students $100 \%$ opined that the communications skills are the important tool for good doctor patient relationship. $28(96.5 \%)$ were confident in treating patients after learning communication skills. 27 $(93.1 \%)$ of the students considered these skills as asset for future practice.

Isabel et al, in their exploratory study on communication skills among medical students before and after the clerkship used SEGUE framework for the assessment of communication skills. ${ }^{17}$ In their study mean age of participants was 22.7 years (SD 0.63). Twenty-six were males $(38.2 \%)$ and 42 were females $(61.8 \%)$.

All students were of same class. In this study mean age of the participants was 28.86 years. $4(13.8 \%)$ were males and $25(86.3 \%)$ were females. $15(51.8 \%)$ students were in $2^{\text {nd }}$ year while $14(48.2 \%)$ students were in $3^{\text {rd }}$ year of their residency programme. The difference in the mean age was due the fact that authors were assessing the communication skills of our residents in their postgraduation and we had included the students of $2^{\text {nd }}$ and $3^{\text {rd }}$ year to increase the sample size of the study group.
There are different observations by different researchers regarding the changes in learned communication skills. ${ }^{18-}$ ${ }^{20}$ In the present study pattern regarding the changes in different communication competencies was uniform and there was statistical improvement in the communication skills assessed by faculty and students themselves as the $p$ value was significant in almost all the communication competencies while a complex pattern was observed by the soft skills assessed by patients and her attendants. Interestingly, gathers information, reaches agreement, provides closure and demonstrates empathy components of skill competencies showed an improvement among patients/attendants assessed residents. This could be due to the greater clinical experience of the residents that have contributed to a more empathic behavior.

\section{CONCLUSION}

The skill to communicate with patients is a fine art that needs to be mastered for being a good clinician. A formal training in effective communication skills is absolutely necessary to bring professionalism in medical practice. The present study points towards the need of regular training in effective communication skills should be included in the medical school curriculum. Such sort of studies on workplace assessment will definitely improve clinical competence of medical professional.

Funding: No funding sources

Conflict of interest: None declared

Ethical approval: The study was approved by the Institutional Ethics Committee

\section{REFERENCES}

1. Coulehan JL, Block MR. The medical interview: mastering skills for clinical practice, $4^{\text {th }}$ ed. Philadelphia: FA Davis Company; 2001.

2. Cole SA, Bird J. Medical interview: the three function approach. Philadelphia: Mosby; 2000:713.

3. Choudhary A, Gupta V. Teaching communication skills to medical students: Introducing the fine art of medical practice. Int $\mathbf{J}$ App Basic Med Res. 2015;5:41-4.

4. Yedidia MJ, Gillespie CC, Kachur E, Schwartz MD, Ockene J, Chepaitis AE, et al. Effect of communications training on medical student performance. JAMA. 2003;290:1157-65.

5. Joekes K, Noble LM, Kubacki AM, Potts HW, Lloyd M. Does the inclusion of 'professional development' teaching improve medical students' communication skills? BMC Med Educ. 2011;11:41.

6. WHO recommendations: intrapartum care for a positive childbirth experience. Geneva: 2018. Available at: https://www.who.int/reproductive health/publications/intrapartum-care-guidelines/en/. Accessed on $10^{\text {th }}$ March 2020.

7. Rowland-Morin PA, Carroll JG. Verbal communication skills and patient satisfaction. Eval Health Prof. 1990;13:168-85. 
8. Shendurnikar N, Thakkar PA. Communication skills to ensure patient satisfaction. Indian $\mathrm{J}$ Pediatr. 2013;80:938-43.

9. VISION 2015. Available at: http://www.mciindia.org/tools/announcement/MCI_b ooklet.pdf. Accessed on 22 ${ }^{\text {nd }}$ March 2017.

10. Rees C, Sheard C, Davies S. The development of a scale to measure medical students' attitudes towards communication skills learning: the communication skills attitude scale (CSAS). Med Educ. 2002;36(2):141-7.

11. Makoul G. Bayer-Fetzer conference on physicianpatient communication in medical education. Essential elements of communication in medical encounters: the Kalamazoo consensus statement. Acad Med. 2001;76:390-93.

12. Rider EA. Interpersonal and Communication Skills. In: Rider EA, Nawotniak RH. A Practical Guide to Teaching and Assessing the ACGME Core Competencies, $2^{\text {nd }}$ edition. Marblehead, MA: HCPro, Inc.; 2010:1-137.

13. Calhoun AW, Rider EA, Meyer EC, Lamiani G, Truog RD. Assessment of communication skills and self-appraisal in the simulated environment: feasibility of multirater feedback with gap analysis. Simul Healthc. 2009;4(1):22-9.

14. Kurtz SM, Silverman JD. The Calgary-Cambridge Referenced Observation Guides: an aid to defining the curriculum and organizing the teaching in communication training programmes. Med Educ. 1996;30(2):83-9.

15. Dias LM, Carvalho AE, Furlaneto IP, Oliveira CG. Medical residents perceptions of communication skills a workshop on breaking bad news. Revista Brasileira de Educação Médica. 2018;42(4):175-83.

16. Wright KB, Bylund C, Ware J, Parker P, Query JL, Baile W. Medical student attitudes toward communication skills training and knowledge of appropriate provider-patient communication: A comparison of first-year and fourth-year medical students. Med Educ Online. 2006:11(1):4594.

17. Isabel TG, Rui MC, Margarida FB. Communication skills in medical students - An exploratory study before and after clerkships. Porto Biomed J. 2016;1(5):173-80.

18. Neumann M, Edelhäuser F, Tauschel D, Fischer MR, Wirtz M, Woopen C, et al. Empathy decline and its reasons: a systematic review of studies with medical students and residents. Acad Med. 2011;86:9961009.

19. Craig JL. Retention of interviewing skills learned by first-year medical students: a longitudinal study. Med Educ. 1992;26:276-81.

20. Engler CM, Saltzman GA, Walker ML, Wolf FM. Medical student acquisition and retention of communication and interviewing skills. J Med Educ. 1981;56:572-9.

Cite this article as: Gupta A, Gupta B, Verma A, Sharma C, Thakur S, Soni A. Assessment of labor room communication skills among postgraduate students of obstetrics and gynecology. Int J Reprod Contracept Obstet Gynecol 2020;9:2281-7. 